\title{
Non-toxic Salvia sclareoides Brot. extracts as a source of functional food ingredients: Phenolic profile, antioxidant activity and prion binding properties
}

\author{
Amélia P. Rauter ${ }^{\mathrm{a}, *}$, Catarina Dias ${ }^{\mathrm{a}}$, Alice Martins ${ }^{\mathrm{a}}$, Isabel Branco ${ }^{\mathrm{a}}$, Nuno R. Neng ${ }^{\mathrm{a}}$, José M. Nogueira ${ }^{\mathrm{a}}$, \\ Margarida Goulart $^{\mathrm{a}, \mathrm{b}}$, Filipa V.M. Silva ${ }^{\mathrm{b}}$, Jorge Justino ${ }^{\mathrm{b}}$, Clare Trevitt $^{\mathrm{c}}$, Jon P. Waltho ${ }^{\mathrm{c}, \mathrm{d}}$ \\ ${ }^{a}$ Universidade de Lisboa, Faculdade de Ciências, Departamento de Química e Bioquímica/Centro de Química e Bioquímica, Edifício C8, $5^{\circ}$ Piso, Campo Grande, \\ 1749-016 Lisboa, Portugal \\ ${ }^{\mathrm{b}}$ Escola Superior Agrária de Santarém, Instituto Politécnico de Santarém, Quinta do Galinheiro, 2001-904 Santarém, Portugal \\ ${ }^{\mathrm{c}}$ Department of Molecular Biology and Biotechnology, The University of Sheffield, Sheffield S10 2TN, UK \\ ${ }^{\mathrm{d}}$ Faculty of Life Sciences and Manchester Interdisciplinary Biocentre, The University of Manchester, Manchester M1 7DN, UK
}

\section{A R T I C L E I N F O}

\section{Article history:}

Received 10 October 2011

Received in revised form 14 November 2011

Accepted 8 December 2011

Available online 16 December 2011

\section{Keywords:}

Salvia sclareoides

Phenolic profile

Antioxidant activity

Cytotoxicity

Genotoxicity

Prion binding

\begin{abstract}
A B S T R A C T
Salvia sclareoides is an aromatic herb native to Portugal, of which phenolic content (Folin-Ciocalteau method), chemical profile (HPLC/DAD), antioxidant activity (DPPH, $\beta$-carotene/linoleic acid assays), acute toxicity (MTT method, adapted for non-adherent cells), genotoxicity (short-term chromosomal aberration assay) and prion binding properties were evaluated in the acetone, water, ethanol, methanol and $n$-butanol extracts. The latter presented the highest phenolic content and antioxidant activity (DPPH assay), and was the single one with the flavonoids (+)-catechin, kaempferol $O$-glucoside and quercetin. Vanillic acid was the major component of all extracts but gallic, gentisic, caffeic, syringic, coumaric and ferulic acids were also found in some extracts. Only the $n$-butanol extract had components binding to the cellular form of human prion protein detected by NMR which showed specificity for two regions of the folded domain and for the unstructured $\mathrm{N}$-terminal region. Extracts were not cytotoxic nor genotoxic, reinforcing the potential of $S$. sclareoides for nutraceutical purposes.
\end{abstract}

(c) 2011 Elsevier Ltd. All rights reserved.

\section{Introduction}

Salvia is one of the largest genera of the Lamiaceae family and is widespread in the Mediterranean region, South-East Asia and Central America. Salvia species are reputed for their medicinal properties and they have been used in folk medicine to treat colds, wounds and skin infections, headache, cerebral ischaemia and memory disorders (Kivrak et al., 2009), as well as hepatitis (Jin, Quian, \& Lu, 2011). Sage (Salvia officinalis) is cultivated in Europe and used as a culinary condiment and a food additive, and in traditional medicine for its antiseptic, astringent and spasmolytic effects. Spanish sage (Salvia lavandulaefolia Vahl.) and sage have also been used against memory loss in European folk medicine (Howes, Perry, \& Houghton, 2003). In traditional Chinese medicine neurological pathologies, such as insomnia, are treated with Salvia miltiorrhiza Bge., which also decreases the intake of alcohol in vivo (Carai et al., 2000).

It is well established that oxidative stress, which results from the presence of excessive quantities of reactive oxygen species in biological systems, may cause cell membrane dysfunction and

\footnotetext{
* Corresponding author. Tel.: +351 217500952; fax: +351 217500088.

E-mail address: aprauter@fc.ul.pt (A.P. Rauter).
}

DNA damage. Many degenerative disorders, namely cardiovascular and brain diseases, arthritis, diabetes, cancer and immune system decline involve cellular damage possibly caused by free radicals. Antioxidant compounds play a crucial role in the treatment of these pathologies by acting as free radical scavengers, thus decreasing the extent of oxidative damage. Hence, evaluation of radical scavenging properties and antioxidant activity is relevant with plants claimed to have medicinal applications. A variety of Salvia species were reported to have promising radical scavenging activities, namely $S$. officinalis (Oboh \& Hente, 2009), Turkish (Senol et al., 2010) and South African (Kamatou, Viljoen, \& Steenkamp, 2010) species.

The antioxidant activity of Salvia species extracts has been related to their total phenolic content in a direct manner: extracts rich in polyphenols (mainly phenolic acids and flavonoids) usually have a higher antioxidant capacity (Tosun et al., 2009). Phenolic acids with antioxidant activity have been isolated from the extracts of the traditional Chinese herb S. miltiorrhiza (Zhao et al., 2011). These polyphenols acting as free radical scavengers have shown beneficial health-promoting effects in chronic and degenerative diseases. Some of them inhibit amyloid fibril formation and a new mechanism of action for these antioxidants has been proposed by Porat, Abramowitz, and Gazit (2006), based on structural constraints and specific aromatic interactions, which direct 
polyphenol inhibitors to the amyloidogenic core. The polyphenols tannic acid, katacine and 2,2-bisepigallocatechin digallate were also studied against prion $\mathrm{PrP}^{\mathrm{Sc}}$ (the infectious form of prion protein) and proved to inhibit the formation of fibrillar assemblies at the $\mu \mathrm{M}$ range (Porat et al., 2006).

More than 20 amyloid-related diseases, including type II diabetes, familial amyloidosis, Alzheimer's, Parkinson's, Huntington's and prion diseases are known, but therapeutical solutions for most of them are missing, which encourages chemists and biologists to further study polyphenols and their neuroprotective effects.

The subject of the present study is Salvia sclareoides, a species native to Portugal which exhibits a potent cholinesterase inhibitory activity (Rauter et al., 2007) of relevance to memory dysfunction and Alzheimer's disease. Extracts induced a significant inhibition of acetylcholinesterase, even at the concentration of $10 \mu \mathrm{g} / \mathrm{ml}$, while the standard drug rivastigmine did not inhibit the enzyme at the same concentration. In addition, extracts from S. sclareoides were found to retard the rate of prion propagation in a cell-based screen (Martins et al., 2009). Herein, extracts from $S$. sclareoides are investigated with the following objectives:

(i) To search for functional food ingredients from S. sclareoides;

(ii) To determine the phenolic profile of $S$. sclareoides extracts obtained with solvents of different polarity;

(iii) To evaluate the antioxidant activity;

(iv) To evaluate the direct cytotoxicity and genotoxicity;

(v) To evaluate whether the extracts interact with human prion protein;

(vi) To demonstrate S. sclareoides benefits for nutraceutical and medicinal purposes.

\section{Experimental}

\subsection{Plant material and extracts preparation}

Aerial parts of S. sclareoides Brot. (Labiatae), collected at the Lizandro Estuary, Mafra, Portugal in May, were identified in the Herbarium João Carvalho Vasconcelos (LISI), Instituto Superior de Agronomia, Universidade Técnica de Lisboa, Portugal, where a voucher specimen was deposited. The air-dried and finely powdered aerial parts $(280 \mathrm{~g})$ of the plant were macerated overnight, in acetone, at room temperature ( $\mathrm{rt}$ ). The macerate was then filtered and concentrated to dryness, at $40{ }^{\circ} \mathrm{C}$, under reduced pressure to give the acetone extract $(11 \mathrm{~g})$. The same procedure was performed to obtain the ethanol extract $(3 \mathrm{~g})$. The $n$-butanol and water extracts were prepared as follows: the aerial parts $(100 \mathrm{~g})$ were extracted firstly with dichloromethane at rt and solvent evaporation under reduced pressure, at $40^{\circ} \mathrm{C}$, gave the dichloromethane extract $(2 \mathrm{~g})$. The plant was then extracted with methanol to give, after evaporation of the solvent, the methanol extract $(5 \mathrm{~g})$. The last extraction was made with a $50 \%$ methanol aqueous solution. Methanol was evaporated and the aqueous phase was extracted with $n$ butanol, to give the butanolic extract $(3 \mathrm{~g})$. Finally, the aqueous phase was concentrated to dryness to give the water extract $(8 \mathrm{~g})$.

\subsection{Determination of total phenolics}

The content of phenolic compounds in S. sclareoides extracts was determined using Folin-Ciocalteau reagent (Miliauskas, Venskutonis, \& Van Beek, 2004). For the preparation of the calibration curve, $20 \mu \mathrm{l}$ aliquots of $0.024,0.075,0.105,0.15$ and $0.18 \mathrm{mg} / \mathrm{ml}$ gallic acid solution in water were mixed with $100 \mu$ of tenfold water diluted Folin-Ciocalteau reagent and $80 \mu \mathrm{l}$ of $7.5 \%(\mathrm{w} / \mathrm{v})$ sodium carbonate solution. After $30 \mathrm{~min}$ at $\mathrm{rt}$, the absorbance was measured at $765 \mathrm{~nm}$ on a UV/visible light spectrophotometer Shimadzu ${ }^{\circledR}$ and the calibration curve was drawn. For the determination of plant extracts phenolic content, $20 \mu$ of extract solution was mixed with the same reagents as described above, and after $1 \mathrm{~h}$ the absorption was measured. The experiment was carried out in triplicate. Total content of phenolic compounds in S. sclareoides extracts, expressed as gallic acid equivalents (GAE), was calculated as follows:

$C=(c \times V) / m$,

where $C$ - total phenol content (mg GAE/g plant extract); $c$ - concentration of gallic acid established from the calibration curve (mg GA/ml); $V$ - volume of gallic acid/Salvia extract solution $(=0.02 \mathrm{ml}) ; m$ - weight of pure plant dry extract $(\mathrm{g})$.

\subsection{HPLC-DAD analysis}

HPLC grade methanol (MeOH, 99.9\%) was purchased from Merck (Darmstadt, Germany) and acetic acid (99.8\%) from Riedelde Haën (Seelze, Germany). Ferulic acid (trans-4-hydroxy-3-methoxycinnamic acid, 99\%), caffeic acid (3,4-dihydroxycinnamic acid, 97\% predominantly trans), syringic acid (4-hydroxy-3,5-dimethoxybenzoic acid, 98\%), gallic acid (3,4,5-trihydroxybenzoic acid, 97\%), gentisic acid (2,5-dihydroxybenzoic acid, 98\%), coumaric acid (trans-4-hydroxycinnamic acid, 98\%), vanillic acid (4-hydroxy-3methoxybenzoic acid, 97\%), (+)-catechin hydrate $[(2 R, 3 S)-2-(3,4-$ dihydroxyphenyl)-3,4-dihydro-1(2H)-benzopyran-3,5,7-triol, 98\%], rutin hydrate $(95 \%)$ and quercetin dehydrate $(98 \%)$ were purchased from Sigma-Aldrich (Buchs, Germany). Chlorogenic acid [1,3,4,5tetrahydroxycyclohexanecarboxylic acid 3-(3,4-dihydroxycinnamate), $\geqslant 95 \%$, and kaempferol 3-O-glucoside ( $\geqslant 99 \%$ ) were purchased from Extrasynthèse (Genay, France). Ultra-pure water was obtained from Milli-Q water purification systems (Millipore, Palm Springs, CA, USA). The stock solutions of individual standards (1000 $\mathrm{mg} \mathrm{l}^{-1}$ ) and samples were prepared in HPLC grade $\mathrm{MeOH}$ and used to prepare the working standard mixtures at the desired concentration. After experimental procedures, the stock solutions and working standards were wrapped in aluminium foil and stored at $-4{ }^{\circ} \mathrm{C}$ to prevent photodegradation.

HPLC-DAD analyses were carried out on an Agilent 1100 Series LC system (Agilent Technologies, Waldbronn, Germany), composed by the following modules: vacuum degasser (G1322A), quaternary pump (G1311A), autosampler (G1313A), thermostatted column compartment (G1316A) and the diode array detector (G1315B). The data acquisition and instrumental control were performed by the software LC3D ChemStation (version Rev.A.10.0 [1757], Agilent Technologies). Analyses were performed on a Mediterranean Sea 18 column, $150 \times 2.1 \mathrm{~mm}, 5 \mu \mathrm{m}$ particle size (Teknokroma, Barcelona, Spain). The mobile phase consisted on a mixture of $\mathrm{MeOH}$ (solvent A) and $2.5 \%$ acetic acid aqueous solution (solvent $\mathrm{B}$ ). The applied gradient was 0-50 min: 30-80\% A, 50-55 min: 80-30\% A and hold at $30 \% \mathrm{~A}$ for $5 \mathrm{~min}$ and the flow rate was $0.5 \mathrm{ml} \mathrm{min}{ }^{-1}$. The analyses were performed at $25^{\circ} \mathrm{C}$ and the injection volume was $10 \mu \mathrm{l}$ with a draw speed of $200 \mu \mathrm{lmin}^{-1}$. The detector was set at $280 \mathrm{~nm}$. For identification purposes, the retention parameters of each extract were compared with the standard controls and the peak purity with the UV-visible spectral reference data.

\subsection{Antioxidant activity}

The antioxidant potential of $S$. sclareoides extracts ( $n$-butanol, ethanol, methanol, acetone and water), was assessed by two spectrophotometric methods: 2,2-diphenyl-1-picrylhydrazyl hydrate (DPPH) free radical scavenging activity and $\beta$-carotene/linoleic acid bleaching assay. Tests were carried out with extracts and reference antioxidants: the synthetic butylated hydroxytoluene (BHT) and the natural antioxidant, ascorbic acid (AA), in concentrations ranging from 1 to $500 \mu \mathrm{g} / \mathrm{ml}$. A blank sample consisting of the 
same reagent mixture and experimental procedure but without extract, BHT or ascorbic acid was also carried out. The reagents (p.a.) DPPH, $\beta$-carotene, linoleic acid, Tween 40, DMSO, methanol, chloroform, ascorbic acid and BHT were purchased from Sigma-Aldrich (Buchs, Switzerland). After performing the activity experiments, each extract/control concentration causing 50\% antioxidant activity $\left(\mathrm{IC}_{50}\right)$ for both methods used, was estimated by mathematical regression from a dose-response curve.

\subsubsection{DPPH free radical scavenging assay}

The DPPH radical scavenging activity of $S$. sclareoides extracts was measured according to Özgen et al (2006), with slight modifications. The DPPH test is based on the ability of the extracts to donate a radical hydrogen to scavenge the stable DPPH radical. When this radical reacts with the antioxidant compound, it is reduced with the loss of the deep violet colour to light-yellow. The absorbance was measured at $517 \mathrm{~nm}$ on a visible light spectrophotometer Shimadzu ${ }^{\circledR}$. Each $S$. sclareoides extract $(20 \mathrm{mg})$ was dissolved in methanol $(1 \mathrm{ml})$, with the exception of the water extract, which was dissolved in ultra-pure water. DPPH solution in methanol $(0.27 \mathrm{mM})$ was prepared daily, before absorbance measurements, and to this solution $(185 \mu \mathrm{l})$, kept in appropriate disposable plastic cuvettes (Plastibrand ${ }^{\circledR}$ ), the extract solution $(15 \mu \mathrm{l})$ was added and the mixture shaken vigorously. Final extract concentration ranged from 1 to $500 \mu \mathrm{g} / \mathrm{ml}$, whereas DPPH solution was $0.25 \mathrm{mM}$. After 30 min incubation in the dark at $\mathrm{rt}$, absorbance at $517 \mathrm{~nm}$ was measured. The experiment was carried out in triplicate. Reference synthetic antioxidant BHT (dissolved in methanol) and natural antioxidant ascorbic acid (dissolved in water) were also tested in the same concentrations of $S$. sclareoides extracts for comparison purposes. A blank sample consisting of the same reagent mixture and experimental procedure but without extract, BHT or ascorbic acid was always carried out. The \%DPPH radical scavenging activity was calculated as follows:

\section{DPPH radical scavenging effect (\%)

$$
=\left[\left(A b s_{\text {blank }}-A b s_{\text {extract }}\right) / A b s_{\text {blank }}\right] \times 100,
$$

where $\mathrm{Abs}_{\text {blank }}$ is the absorbance of the blank sample (time $=30$ min) and $\mathrm{Abs}_{\text {extract }}$ is the absorbance of the sample with the plant extract (time $=30 \mathrm{~min}$ ).

\subsection{2. $\beta$-Carotene/linoleic acid bleaching assay}

The $\beta$-carotene bleaching test estimates the capacity of a plant extract solution to inhibit $\beta$-carotene oxidation in the presence of linoleic acid in pro-oxidation conditions. The acetone, $n$-butanol, ethanol, methanol extracts of $S$. sclareoides and BHT were solubilised in DMSO, whereas plant water extract and ascorbic acid solutions were prepared with distilled water. The antioxidant activity of $S$. sclareoides extracts using the $\beta$-carotene/linoleic acid assay was measured according to Miller (1971) with minor modifications. Briefly, a stock solution of $\beta$-carotene/linoleic acid mixture was prepared as follows: $\beta$-carotene $(0.2 \mathrm{mg})$ was dissolved in chloroform $(1 \mathrm{ml})$ and then linoleic acid $(22 \mu \mathrm{l})$ and Tween 40 (200 mg) were added. Chloroform was completely evaporated using a vacuum evaporator. Then, distilled water saturated with oxygen $(40 \mathrm{ml})$ was added under vigorous shaking. The reaction mixture ( $2 \mathrm{ml}$ ) was dispensed into test tubes, and each plant extract solution $(0.5 \mathrm{ml})$ was added. The mixture containing the plant extract or the control antioxidants was incubated at $50{ }^{\circ} \mathrm{C}$ for $2 \mathrm{~h}$ and absorbances were acquired along the incubation period at $470 \mathrm{~nm}$. BHT and ascorbic acid were used as standards. The experiments were carried out in duplicate. The final concentrations of chemicals in the test were as follows:
[ $\beta$-Carotene $]=4 \mu \mathrm{g} / \mathrm{ml} ;$ [Linoleic acid $]=400 \mu \mathrm{g} / \mathrm{ml} ;$ [Salvia extract $]=1-500 \mu \mathrm{g} / \mathrm{ml}$. The antioxidant activity (AA) was calculated from the oxidation rates $(R)$ as follows:

$\operatorname{Ln}(\mathrm{Abs})=\ln \left(\mathrm{Abs}_{0}\right)+R \times t$, where $R$, the bleaching rate, is the slope of $\ln (\mathrm{Abs})$ vs. time line, which can be calculated by linear regression, being $t$ the time in minutes.

$\mathrm{AA}(\%)=\left[\left(R_{\text {blank }}-R_{\text {extract }}\right) / R_{\text {blank }}\right] \times 100$, where $R_{\text {blank }}$ and $R_{\text {extract }}$ are the oxidation rates of blank sample and sample containing the extract, respectively.

\subsection{Toxicity studies}

Acute toxicity assessment was performed by the MTT method adapted for non-adherent cells (Young, Phungtamdet, \& Sanderson, 2005). The 3-(4,5-dimethylthiazol-2-yl)-2,5-diphenyltetrazolium bromide (MTT) assay was performed to quantify metabolically viable cells in all samples. Suspension cells (K562 human erythroblastoid cell line) were seeded onto 96-well plates, allowed to divide for $24 \mathrm{~h}$ and exposed to the test compounds for the following $24 \mathrm{~h}$. Positive controls (hydrogen peroxide) and negative controls (pure solvent) were also included. After $48 \mathrm{~h}$ of culture, MTT was added to the cells at a final concentration of $0.5 \mathrm{mg} / \mathrm{ml}$, followed by an incubation period of $3 \mathrm{~h}$ to allow the formazan crystals to form. After the incubation time, DMSO $(100 \mu \mathrm{l})$ was added to each well. Solubilisation of formazan crystals was performed by agitation in a 96-well plate shaker for $20 \mathrm{~min}$ at $\mathrm{rt}$. Absorbance of each well was quantified at $550 \mathrm{~nm}$ using $620 \mathrm{~nm}$ as reference wavelength on a scanning multiwell spectrophotometer (automated plate reader). Genotoxicity was assessed by the short-term in vitro chromosomal aberration assay according to Rueff et al. (1993). Briefly, cell cultures of peripheral blood lymphocytes from healthy donors were set up, and lymphoproliferation was induced with phytohemagglutinnin ( $2 \% \mathrm{v} / \mathrm{v}, 24 \mathrm{~h}$ incubation). Cells were exposed to the plant extracts for $24 \mathrm{~h}$, and then colcemid, at a final concentration of $0.5 \mu \mathrm{g} / \mathrm{ml}$, was added during the last $3 \mathrm{~h}$ of culture, to stop the dividing cells in the metaphase stage of mitosis. Metaphase spreads were obtained in standard glass microscopy slides, pre-washed and covered with a thin water film. Scoring was performed in a Zeiss optical microscope at $1250 \times$ magnification, by observing 100 complete metaphases (presenting 46 centromers) per case. Classification of chromosomal aberrations was done according to criteria described by Rueff et al. (1993). The mitotic index was also quantified by counting the number of metaphases per 1000 nuclei.

\subsection{Interaction with human prion protein}

S. sclareoides acetone, methanol, ethanol, $n$-butanol and water extracts were dissolved in $\mathrm{d}_{6}$-DMSO at approximately $100 \mathrm{mg} / \mathrm{ml}$. NMR samples $(0.5 \mathrm{ml})$ were prepared through the addition of the extract solutions (to a final concentration of approximately $1 \mathrm{mg} /$ $\mathrm{ml}$ ) to a solution containing $100 \mu \mathrm{M}$ uniformly ${ }^{15} \mathrm{~N}$-labelled human prion protein (residues $91-231$; huPrP $_{91-231}$ ) at pH 5.5 in $20 \mathrm{mM}$ sodium acetate, $0.02 \%$ sodium azide, $10 \% \mathrm{D}_{2} \mathrm{O}$ and $10 \% \mathrm{~d}_{6}$-DMSO. NMR spectra were acquired at $298 \mathrm{~K}$ on a Bruker DRX-800 spectrometer equipped with a $5 \mathrm{~mm}{ }^{13} \mathrm{C} /{ }^{15} \mathrm{~N} /{ }^{1} \mathrm{H}$ triple-resonance probe. Proton chemical shifts were referenced to $1 \mathrm{mM}$ TSP added to the samples. ${ }^{15} \mathrm{~N}$ chemical shifts were calculated relative to TSP, using the gyromagnetic ratios of ${ }^{15} \mathrm{~N}$ and ${ }^{1} \mathrm{H}\left({ }^{15} \mathrm{~N} /{ }^{1} \mathrm{H} 0.101329118\right)$. NMR data were processed and analysed on Linux Workstations using Felix 2007 (Accelrys, San Diego, CA) software. ${ }^{15} \mathrm{~N}-\mathrm{HSQC}$ spectra of the huPrP $\mathrm{P}_{91-231}$-salvia extract samples were analysed for perturbation of huPrP $91-231$ resonances relative to control samples, in which the extracts were omitted. Intensity changes of huPrP $P_{91-231}$ resonances were displayed on the 3D structure of 
huPrP $91-231$ using spheres with radii corresponding to the percentage loss of resonance intensity.

\section{Results and discussion}

\subsection{Chemical analysis}

The total phenolic content (TPC) of each extract was first determined. The $n$-butanol extract had the highest TPC value (379 mg GAE/g dry extract), while the lowest one (22 mg GAE/ g dry extract) was exhibited by the water extract (Table 1). Moreover, TPC of the $S$. sclareoides $n$-butanol extract was higher than those reported for South African Salvia species (45.6-212 mg GAE/g dry extract) (Kamatou et al., 2010) and for the Turkish plant Salvia fruticosa, where a TPC of $87.9 \mathrm{mg} \mathrm{GAE} / \mathrm{g}$ dry extract was given for a dichloromethane extract (Senol et al., 2010). The TPC of $S$. sclareoides is, however, consistent with the one reported for the ethanolic extract of Salvia juduica (380.5 mg GAE/g dry extract) evaluated by the Folin Dennis method (Al-Ismail, Herzallah, \& Rustom, 2007).

The chemical profile was determined by HPLC-DAD. Optimisation of the system was performed in order to achieve convenient instrumental conditions to analyse the standard phenolic compounds (Table 1). Preliminary assays indicated that all the 12 standards resolve in a suitable analytical time. Subsequently, acetone, ethanol, methanol and $n$-butanol extracts of $S$. sclareoides were analysed under the same instrumental conditions, but the water extract could not be studied under these conditions because its components were above the limit of detection at $280 \mathrm{~nm}$. The relative percentages of phenolic compounds present in those extracts are depicted in Table 1. Amongst the analysed samples, the acetone and $n$-butanol extracts are those that showed the highest number of phenolic compounds, 8 and 9, respectively, out of the 12 standards used. Vanillic acid was the major component of all extracts. This phenolic acid has antisickling and anthelmintic activities and suppressed hepatic fibrosis in chronic liver injury (Itoh et al., 2010; Khadem \& Marles, 2010). Syringic acid, only present in the acetone extract, is also known for its hepatoprotective effects (Itoh et al., 2010) while gentisic acid, mainly present in the same extract, has analgesic, anti-inflammatory, antirheumatic, and cytostatic properties, inhibiting also low density lipoprotein oxidation and the formation of cholesterol ester hydroperoxides in human plasma (Ashidate et al., 2005). Gallic acid, present in all extracts, has a variety of bioactivities, namely antineoplastic, bacteriostatic, antimelanomagenic, antioxidant properties, and has been proposed as candidate for the treatment of brain tumours (Lu et al., 2010). Chlorogenic acid was found in the methanol and $n$-butanol extracts and its protective effect against neurotoxocity reducing

\section{Table 1}

Relative percentage of phenolics in Salvia sclareoides extracts evaluated by HPLC-DAD at $280 \mathrm{~nm}$.

\begin{tabular}{lcllll}
\hline Standards & \multirow{2}{*}{ Rt $(\mathrm{min})$} & \multicolumn{2}{l}{ Extracts } & & \\
\cline { 3 - 6 } & & MeOH & EtOH & BuOH & Acetone \\
\hline Gallic acid & 1.189 & 0.8 & 0.8 & 1.2 & 1.7 \\
(+)-Catechin & 3.421 & - & - & 0.5 & - \\
Gentisic acid & 4.085 & - & 1.0 & - & 3.6 \\
Chlorogenic acid & 4.346 & 1.1 & - & 1.3 & - \\
Caffeic acid & 5.085 & - & 0.8 & 1.4 & 2.4 \\
Vanillic acid & 5.551 & 2.5 & 1.3 & 2.8 & 6.9 \\
Syringic acid & 6.680 & - & - & - & 2.1 \\
Coumaric acid & 9.692 & 1.3 & 0.1 & 0.6 & 0.8 \\
Ferulic acid & 12.876 & 0.8 & - & 0.5 & 0.1 \\
Rutin hydrate & 25.104 & - & - & - & 1.6 \\
Kaempferol $O$-glucoside & 32.302 & - & - & 0.7 & - \\
Quercetin dehydrate & 36.658 & - & - & 1.4 & - \\
\hline
\end{tabular}

apoptosis induced by beta-amyloid (A beta) was recently reported (Lee et al., 2011). In addition, it exhibits anticholinesterase and free radical scavenging activities and may exert anti-amnesic activity (Kwon et al., 2010). The antioxidant, anti-inflammatory and immunostimulatory ferulic acid (Chao \& Lin, 2011) promotes degeneration of recombinant beta-amyloid peptide, as described by Picone et al. (2009). Also caffeic acid has neuroprotective effects against A beta-induced toxicity by the inhibition of calcium influx and tau phosphorylation (Sul et al., 2009), and protects neuronal cells against oxidative stress induced cytotoxicity (Jeong et al., 2011). Both caffeic and coumaric acids are capable of inducing neuroprotective effects in Parkinson's disease (Vauzour, Corona, \& Spencer, 2010) to a similar extent to that seen with the flavonoids (+)-catechin and quercetin, also present in the $n$-butanol extract (Martin, Gonzalez-Burgos, Carretero, \& Gomez-Serranillos, 2011). Not only quercetin but also rutin, present in the acetone extract alone, are known to revert cognitive deficits (Tongjaroenbuangam et al., 2011). Kaempferol O-glucoside also contributes to the nutraceutical relevance of this plant considering the wide range of pharmacological activities, including neuroprotective properties known for kaempferol glycosides (Calderon-Montano, Burgos-Moron, PerezGuerrero, \& Lopez-Lazaro, 2011).

Studies with animal models with a supplemented diet with polyphenols have produced neuroprotection and favourable effects concerning age-related cognitive and motor decline (Giacalone et al., 2011). The present results reinforce the importance of S. sclareoides for its traditional use as food condiment and medicinal plant, and as a source of functional food ingredients against neurodegenerative diseases.

\subsection{Antioxidant activity}

\subsubsection{DPPH radical scavenging activity}

The antioxidant activity of $S$. sclareoides extracts was determined using the DPPH radical scavenging method (Table 2). The $n$-butanol extract was the most bioactive with an $\mathrm{IC}_{50}=7.9 \mu \mathrm{g} /$ $\mathrm{ml}$. This extract was more active than the synthetic antioxidant BHT $\left(\mathrm{IC}_{50}=29.7 \mu \mathrm{g} / \mathrm{ml}\right)$ used as control, and showed an antioxidant strength of the same order of magnitude as ascorbic acid, a natural antioxidant $\left(\mathrm{IC}_{50}=4.9 \mu \mathrm{g} / \mathrm{ml}\right)$. Methanol and ethanol extracts had $\mathrm{IC}_{50}$ values of 114 and $134 \mu \mathrm{g} / \mathrm{ml}$, respectively, while the water extract was the least active one, with a DPPH radical scavenging activity (RSA) of $19.6 \%$ at $500 \mu \mathrm{g} / \mathrm{ml}\left(\mathrm{IC}_{50}>500 \mu \mathrm{g} / \mathrm{ml}\right)$.

\subsection{2. $\beta$-Carotene/linoleic acid bleaching assay}

The antioxidant activity of the extracts was also assessed using the $\beta$-carotene/linoleic acid method (Table 2). In this assay, the acetone extract presented the highest activity $\left(\mathrm{IC}_{50}=38.4 \mu \mathrm{g} / \mathrm{ml}\right)$, which is of the same order of magnitude as that exhibited by ascorbic acid $\left(\mathrm{IC}_{50}=26.1 \mu \mathrm{g} / \mathrm{ml}\right)$. Similar values were obtained for the $n$ butanol, methanol, ethanol and water extracts. In contrast to the relatively high antioxidant activity observed with the $n$-butanol extract using the DPPH method, the capacity of this extract to inhibit $\beta$-carotene oxidation did not differ significantly from that of the other extracts.

\subsection{Acute cytotoxicity and genotoxicity}

Acute toxicity and genotoxicity were assessed in vitro using peripheral blood human lymphocytes and K562 human lymphoblast immortalised cells. Cells tested with a final extract concentration of up to $4 \mathrm{mg} / \mathrm{ml}$ showed no evidence of toxicity. The viability of the cells was not affected and no evidence of genotoxic risk was observed (Table 3). 
Table 2

Antioxidant activity (\%), $\mathrm{IC}_{50}{ }^{\mathrm{b}}$ and total phenolic content ${ }^{\mathrm{c}}$ of Salvia sclareoides extracts.

\begin{tabular}{|c|c|c|c|c|c|c|c|c|c|c|}
\hline \multirow[t]{2}{*}{ Extract } & \multirow[t]{2}{*}{ Method } & \multicolumn{7}{|c|}{ S. sclareoides extract concentration $(\mu \mathrm{g} / \mathrm{mL})$} & \multirow[t]{2}{*}{$\mathrm{IC}_{50}(\mu \mathrm{g} / \mathrm{mL})$} & \multirow[t]{2}{*}{ TPC (mg GAE/g dry extract) } \\
\hline & & 1 & 3 & 5 & 10 & 50 & 100 & 500 & & \\
\hline \multirow[t]{2}{*}{ Acetone } & DPPH & $<5$ & $<5$ & $<5$ & $<5$ & $6.1 \pm 0.8$ & $13.9 \pm 1.2$ & $30.5 \pm 2.1$ & $>500$ & \multirow[t]{2}{*}{$67.0 \pm 2.7$} \\
\hline & $\beta$-Carotene & $6.9 \pm 2.8$ & $19.2 \pm 4.4$ & $39.6 \pm 11.9$ & $35.2 \pm 3.4$ & $51.6 \pm 1.7$ & $54.4 \pm 2.3$ & $80.8 \pm 4.5$ & 38.4 & \\
\hline \multirow[t]{2}{*}{ Butanol } & DPPH & $<5$ & $6.1 \pm 2.0$ & $32.9 \pm 2.4$ & $53.9 \pm 0.7$ & $56.9 \pm 4.0$ & $58.7 \pm 3.5$ & $59.5 \pm 2.9$ & 7.9 & \multirow[t]{2}{*}{$379.4 \pm 2.7$} \\
\hline & $\beta$-Carotene & $<5$ & $25.2 \pm 1.7$ & $29.4 \pm 3.9$ & $32.4 \pm 4.0$ & $40.0 \pm 3.4$ & $54.0 \pm 0.6$ & $76.4 \pm 1.7$ & 57.6 & \\
\hline \multirow[t]{2}{*}{ Methanol } & DPPH & $<5$ & $<5$ & $<5$ & $<5$ & $5.3 \pm 1.3$ & $42.9 \pm 3.9$ & $47.7 \pm 1.8$ & 113.9 & \multirow[t]{2}{*}{$120.4 \pm 2.7$} \\
\hline & $\beta$-Carotene & $<5$ & $5.7 \pm 11.1$ & $19.3 \pm 2.3$ & $17.3 \pm 0.6$ & $53.9 \pm 2.4$ & $58.4 \pm 5.7$ & $76.1 \pm 2.2$ & 60.6 & \\
\hline \multirow[t]{2}{*}{ Ethanol } & DPPH & $<5$ & $<5$ & $<5$ & $<5$ & $6.6 \pm 4.8$ & $37.2 \pm 4.8$ & $40.9 \pm 2.5$ & 133.7 & \multirow[t]{2}{*}{$140.8 \pm 4.7$} \\
\hline & $\beta$-Carotene & $<5$ & $<5$ & $16.5 \pm 2.8$ & $26.0 \pm 2.8$ & $37.6 \pm 7.9$ & $47.6 \pm 0.6$ & $81.2 \pm 9.6$ & 78.6 & \\
\hline \multirow[t]{2}{*}{ Water } & DPPH & $<5$ & $<5$ & $<5$ & $<5$ & $3.9 \pm 6.2$ & $13.7 \pm 4.5$ & $19.6 \pm 4.1$ & $>500$ & \multirow[t]{2}{*}{$22.4 \pm 0.7$} \\
\hline & $\beta$-Carotene & $<5$ & $<5$ & $9.7 \pm 7.2$ & $34.3 \pm 0.7$ & $52.4 \pm 6.1$ & $51.2 \pm 4.2$ & $65.1 \pm 0.5$ & 85.1 & \\
\hline \multirow[t]{2}{*}{$\mathrm{AA}$} & DPPH & $3.0 \pm 2.1$ & $31.0 \pm 2.9$ & $48.5 \pm 0.8$ & $70.9 \pm 1.5$ & $72.8 \pm 1.1$ & $71.1 \pm 2.1$ & $73.1 \pm 0.6$ & 4.9 & \multirow[t]{2}{*}{ - } \\
\hline & $\beta$-Carotene & $23.1 \pm 6.8$ & $26.1 \pm 8.2$ & $32.1 \pm 3.3$ & $39.8 \pm 2.3$ & $61.6 \pm 1.2$ & $68.3 \pm 6.8$ & $71.8 \pm 5.2$ & 26.1 & \\
\hline \multirow[t]{2}{*}{ BHT } & DPPH & $<5$ & $7.4 \pm 1.8$ & $9.6 \pm 2.7$ & $34.1 \pm 2.7$ & $59.8 \pm 1.1$ & $59.7 \pm 0.7$ & $61.3 \pm 0.7$ & 29.7 & \multirow[t]{2}{*}{ - } \\
\hline & $\beta$-Carotene & $44.6 \pm 10.9$ & $68.8 \pm 0.0$ & $81.2 \pm 1.7$ & $72.2 \pm 0.9$ & $86.0 \pm 1.7$ & $84.0 \pm 1.1$ & $92.7 \pm 2.1$ & 0.27 & \\
\hline
\end{tabular}

${ }^{\text {a }}$ Results of antioxidant activity in percentage are expressed as the average \pm standard deviation of three replicates; AA (Ascorbic acid) and BHT (butylated hydroxytoluene) are antioxidants used as controls for comparison purposes.

${ }^{\mathrm{b}} \mathrm{IC}_{50}$ is the concentration causing $50 \%$ antioxidant activity estimated by non-linear regression.

c Total phenol content, TPC, is expressed in mg of gallic acid equivalents (GAE) per g of dry Salvia extract.

Table 3

In vitro toxicity of Salvia sclareoides extracts: acute toxicity $(4.0 \mathrm{mg} / \mathrm{ml})$ in human immortalised leukaemia cells (K562) and genotoxicity study $(1.9 \mathrm{mg} / \mathrm{ml})$ in human peripheral blood lymphocytes.

\begin{tabular}{|c|c|c|c|}
\hline \multirow{2}{*}{$\begin{array}{l}\text { S. sclareoides } \\
\text { extract }\end{array}$} & \multirow{2}{*}{$\begin{array}{l}\text { Acute toxicity } \\
\text { Cellular viability } \\
\text { (percentage of blank) }\end{array}$} & \multicolumn{2}{|c|}{ Genotoxicity } \\
\hline & & $\begin{array}{l}\text { Mitotic } \\
\text { index }\end{array}$ & $\begin{array}{l}\text { Chromosomal } \\
\text { aberrations }\end{array}$ \\
\hline Acetone & - & $10.50 \pm 4.1$ & $1.25 \pm 1.3$ \\
\hline Butanol & $151.5 \pm 52.6$ & $10.25 \pm 2.2$ & $1.00 \pm 1.2$ \\
\hline Methanol & $140.6 \pm 68.2$ & n.d & n.d. \\
\hline Ethanol & $105.2 \pm 46.9$ & $9.25 \pm 3.8$ & $0.75 \pm 1.0$ \\
\hline Water & $79.3 \pm 28.0$ & $14.00 \pm 3.7$ & $1.00 \pm 0.8$ \\
\hline \multicolumn{4}{|l|}{ Controls } \\
\hline Blank & $100 \pm 37.5$ & $12.75 \pm 3.3$ & $1.00 \pm 0.8$ \\
\hline $\mathrm{H}_{2} \mathrm{O}_{2} 2 \%$ & $34 \pm 17.6$ & $1.75 \pm 1.0$ & $5.00 \pm 2.2$ \\
\hline
\end{tabular}

n.d. - not determined.

\subsection{Interaction with human prion protein}

In order to probe the relationship between S. sclareoides extracts and prion propagation, we have investigated whether the extracts characterised above display any specific interactions with the cellular form of human prion protein $\left(\mathrm{PrP}^{\mathrm{C}}\right)$. $\operatorname{PrP}^{\mathrm{C}}$ is the substrate for formation of the pathological form of the protein $\left(\mathrm{PrP}^{\mathrm{Sc}}\right)$, and is a candidate for anti-prion therapeutics (Mallucci \& Collinge, 2005; Nicoll, 2009). The stabilisation of the $\operatorname{PrP}^{C}$ resulting from ligand binding has the potential to inhibit or delay the pathological cascade that is initiated by conformational change of the protein.

The effects of individual extracts on the NMR spectra of recombinant human prion protein (huPrP $P_{91-231}$ ) were probed using a ${ }^{15} \mathrm{~N}-\mathrm{HSQC}$-perturbation assay (Nicoll et al., 2010). Only the $n$-butanol extract caused any perturbation of the protein resonances, which manifested as an attenuation of specific resonances in the spectrum (Fig. 1). The residues with affected resonances reside in three separate regions of the protein: residues 93-112 (in the unstructured $\mathrm{N}$-terminal region of $\mathrm{PrP}^{\mathrm{C}}$ ), 130-187 (comprising the two strands of the beta sheet, helix 1 and the beginning of helix 2 ), and 205-225 in helix 3 at the C-terminus of the structured domain. Such attenuation of resonances is normally associated with ligand exchange dynamics, and is commonly observed under non-saturating conditions for ligands with dissociation constants in the $\mu \mathrm{M}$ range. While the exact location of ligand binding is not unambiguously determined by the measurements, there is

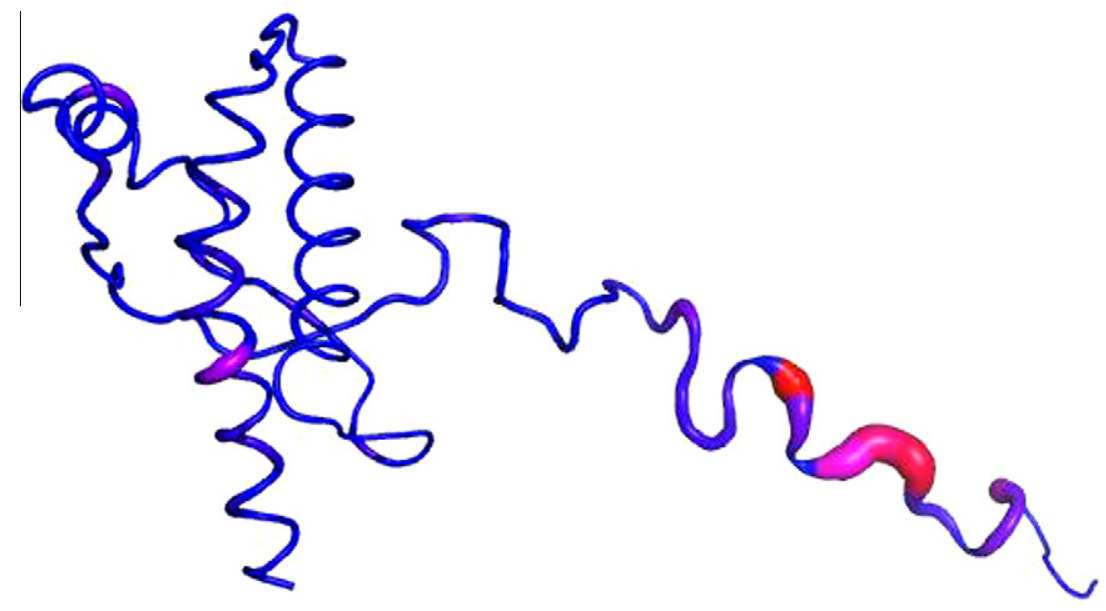

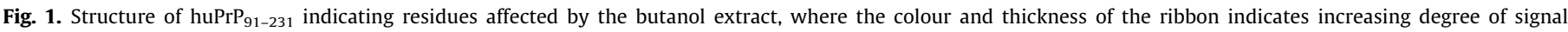

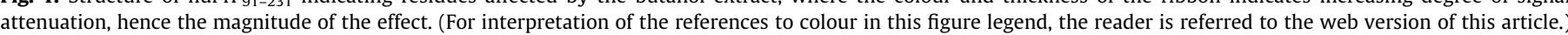


clearly some specific binding of components within the $n$-butanol extract to $\operatorname{PrP}^{\mathrm{C}}$ and, most likely, associated changes in conformation in the folded domain and conformational restriction in the $\mathrm{N}$-terminal region.

\section{Conclusion}

The present study establishes $S$. sclareoides as a viable source of functional food ingredients, due to its high antioxidant and radical scavenging activities, as well as prion binding properties. The NMR measurements showed that components extracted from S. sclareoides had the capability to bind to the cellular form of human prion protein in a specific manner, and hence provide the potential to compete against the recruitment of prion protein into its pathological cascade. The active component(s) were present in the $n$-butanol extract alone and binding caused conformational perturbation in three separate regions of the protein, including the highly dynamic N-terminal region. The $n$-butanol extract is also the richest one in phenolics, which are increasingly of interest in the food industry, and shows promise for neurodegenerative diseases. Furthermore, the tested extracts are neither cytotoxic nor genotoxic, endorsing $S$. sclareoides as a promising plant for nutraceutical and medicinal purposes.

\section{Acknowledgements}

The authors thank FCT (Fundação para a Ciência Tecnologia) for the financial support of project PTDC/AGR-AAM/66414/2006 and two Post-Doctoral Grants (SFRH/BPD 14408/2003 and SFRH/ BPD20902/2004). Further support from The British Council and CRUP via the Treaty of Windsor Anglo-Portuguese Joint Research Program is also gratefully acknowledged. We thank Beining Chen (University of Sheffield) for sharing unpublished data and for the gift of uniformly ${ }^{15} \mathrm{~N}$-labelled human prion protein.

\section{References}

Al-Ismail, K., Herzallah, S. M., \& Rustom, A. S. (2007). Antioxidant activities of some edible wild mediterranean plants. Italian Journal of Food Science, 19, 287-296.

Ashidate, K., Kawamura, M., Mimura, D., Tohda, H., Miyazaki, S., Teramoto, T., et al. (2005). Gentisic acid, an aspirin metabolite, inhibits oxidation of low-density lipoprotein and the formation of cholesterol ester hydroperoxides in human plasma. European Journal of Pharmacology, 513, 173-179.

Calderon-Montano, J. M., Burgos-Moron, E., Perez-Guerrero, C., \& Lopez-Lazaro, M. (2011). A review on the dietary flavonoid kaempferol. Mini-Reviews in Medicinal Chemistry, 11(4), 298-344.

Carai, M. A. M., Agabio, R., Bombardelli, E., Bourov, I., Gessa, G. L., Lobina, C., et al. (2000). Potential use of medicinal plants in the treatment of alcoholism. Fitoterapia, 71(1), S38-S42.

Chao, W., \& Lin, B. (2011). Bioactivities of major constituents isolated from Angelica sinensis (Danggui). Chinese medicine, 6, 29-35.

Giacalone, M., Di Sacco, F., Traupe, I., Topini, R., Forfori, F., \& Giunta, F. (2011). Antioxidant and neuroprotective properties of blueberry polyphenols: A critical review. Nutritional Neuroscience, 14(3), 119-125.

Howes, M.-J., Perry, N. S. L., \& Houghton, P. J. (2003). Plants with traditional uses and activities, relevant to the management of Alzheimer's disease and other cognitive disorders. Phytotherapy Research, 17, 1-18.

Itoh, A. Isoda, K., Kondoh, M., Kawase, M., Watari, A., Kobayashi, M., et al. (2010). Hepatoprotective effect of syringic acid and vanillic acid on $\mathrm{CCl}_{4}$-induced liver injury. Biological \& Pharmaceutical Bulletin, 33, 983-987.

Jeong, C., Jeong, H., Choi, G., Kim, D., Lee, U., \& Heo, H. (2011). Neuroprotective and anti-oxidant effects of caffeic acid isolated from Erigeron annuus leaf. Chinese medicine, 6, 25-34

Jin, X. F., Quian, J., \& Lu, Y. H. (2011). The role of hepatoprotective effect of a flavonoid-rich extract of Salvia plebeia R.Br. on carbon tetrachloride-induced acute hepatic injury in mice. Journal of Medicinal Plants Research, 5(9), 1558-1563.

Kamatou, G. P. P., Viljoen, A. M., \& Steenkamp, P. (2010). Antioxidant, antiinflammatory activities and HPLC analysis of South African Salvia species. Food Chemistry, 119, 684-688.
Khadem, S., \& Marles, R. (2010). Monocyclic phenolic acids; hydroxy- and polyhydroxybenzoic acids: Occurrence and recent bioactivity studies. Molecules, 15(11), 7985-8005.

Kivrak, I., Duru, M. E., Ozturk, M., Mercan, N., Harmandar, M., \& Topcu, G. (2009). Antioxidant, anticholinesterase and antimicrobial constituents from the essential oil and ethanol extract of Salvia potentillifolia. Food Chemistry, 116, 470-479.

Kwon, S., Lee, H., Kim, J., Hong, S., Kim, H., Jo, T., et al. (2010). Neuroprotective effects of chlorogenic acid on scopolamine-induced amnesia via antiacetylcholinesterase and anti-oxidative activities in mice. European Journal of Pharmacology, 649, 210-217.

Lee, C. W. Won, T. J., Kim, H. R., Lee, D., Hwang, K. W., \& Park, S. Y. (2011). Protective effect of chlorogenic acid against A beta-induced neurotoxicity. Biomolecules $\mathcal{E}$ Therapeutics, 19(2), 181-186.

Lu, Y., Jiang, F., Jiang, H., Wu, K., Zheng, X., Cai, Y., et al. (2010). Gallic acid suppresses cell viability, proliferation, invasion and angiogenesis in human glioma cells. European Journal of Pharmacology, 641, 102-107.

Mallucci, G., \& Collinge, J. (2005). Rational targeting for prion therapeutics. Nature Reviews Neuroscience, 6, 23-34.

Martin, S., Gonzalez-Burgos, E., Carretero, M. E., \& Gomez-Serranillos, M. P. (2011). Neuroprotective properties of Spanish red wine and its isolated polyphenols on astrocytes. Food Chemistry, 128(1), 40-48.

Martins, A., Araújo, M. E., Branco, I., Meireles, M., Almeida, J., Sepulveda, C., Neng, N., Nogueira, J., Jacob, P., Goulart, M., Justino, J., Blackburn, G. M., Chen, B. \& Rauter, A. P. (2009). Evaluation of plant extracts against prion diseases and cancer", 42nd IUPAC Congress - Chemistry Solutions, Session for Chemistry for Health Chemistry in the Food Chain and Health, Glasgow, UK.

Miliauskas, G., Venskutonis, P. R., \& Van Beek, T. A. (2004). Screening of radical scavenging activity of some medicinal and aromatic plant extracts. Food Chemistry, 85, 231-237.

Miller, H. E. (1971). A simplified method for the evaluation of antioxidants. Journal of the American Oil Chemists' Society, 48, 91.

Nicoll, A. J., \& Collinge, J. (2009). Preventing prion pathogenicity by targeting the cellular prion protein. Infectious Disorders - Drug Targets, 9, 48-57.

Nicoll, A. J., Trevitt, C. R., Tattum, M. H., Risse, E., Quaterman, E., Ibarra, A. A., et al. (2010). A pharmacological chaperone for the structured domain of human prion protein. Proceedings of the National Acadamy of Sciences USA, 41, $17610-17615$

Oboh, G., \& Hente, T. (2009). Antioxidant and inhibitory effects of aqueous extracts of Salvia officinalis leaves on pro-oxidant-induced lipid peroxidation in brain and liver in vitro. Journal of Medicinal Food, 12(1), 77-84.

Özgen, U., Mavi, A., Terzi, Z., Yuldurum, A., Coskun, M., \& Houghton, P. J. (2006). Antioxidant properties of some medicinal Lamiacae (Labiatae) species. Pharmaceutical Biology, 44, 107-112.

Picone, P., Bondi, M. L., Montana, G., Bruno, A., Pitarresi, G., Giammona, G., et al. (2009). Ferulic acid inhibits oxidative stress and cell death induced by $\mathrm{Ab}$ oligomers: Improved delivery by solid lipid nanoparticles. Free Radical Research, 43(11), 1133-1145.

Porat, Y., Abramowitz, A., \& Gazit, E. (2006). Inhibition of amyloid fibril formation by polyphenols: Structural similarity and aromatic interactions as a common inhibition mechanism. Chemical Biology and Drug Design, 67. 27-37.

Rauter, A. P., Branco, I., Lopes, R. G., Justino, J., Silva, F. V. M., Noronha, J. P., et al. (2007). A new lupene triterpenetriol and anticholinesterase activity of Salvia sclareoides. Fitoterapia, 78, 474-481.

Rueff, J., Brás, A., Cristóvão, L., Mexia, J., Sá da Costa, M., \& Pires, V. (1993). DNA strand breaks and chromosomal aberrations induced by $\mathrm{H}_{2} \mathrm{O}_{2}$ and ${ }^{60} \mathrm{Co} \gamma-$ radiation. Mutation Research, 289, 197-204.

Senol, S., Orhan, I., Celep, F., Kahraman, A., Doğan, M., Yilmaz, G., et al. (2010). Survey of 55 Turkish Salvia taxa for their acetylcholinesterase inhibitory and antioxidant activities. Food Chemistry, 120, 34-43.

Sul, D., Kim, H., Lee, D., Joo, S., Hwang, K., \& Park, S. (2009). Protective effect of caffeic acid against beta-amyloid-induced neurotoxicity by the inhibition of calcium influx and tau phosphorylation. Life Sciences, 84, 257-262.

Tongjaroenbuangam, W., Ruksee, N., Chantiratikul, P., Pakdeenarong, N., Kongbuntad, W., \& Govitrapong, P. (2011). Neuroprotective effects of quercetin, rutin and okra (Abelmoschus esculentus Linn.) in dexamethasonetreated mice. Neurochemistry international, 59, 677-685.

Tosun, M., Ercisli, S., Sengul, M., Ozer, H., Polat, T., \& Ozturk, E. (2009). Antioxidant properties and total phenolic content of eight Salvia species from Turkey. Biological Research, 42(2), 175-181.

Vauzour, D., Corona, G., \& Spencer, J. (2010). Caffeic acid, tyrosol and p-coumaric acid are potent inhibitors of 5-S-cysteinyl-dopamine induced neurotoxicity. Archives of Biochemistry and Biophysics, 501(1), 106-111.

Young, F. M., Phungtamdet, W., \& Sanderson, B. J. (2005). Modification of MTT assay conditions to examine the cytotoxic effects of amitraz on the human lymphoblastoid cell line, WIL2NS. Toxicology In Vitro, 19, 1051-1959.

Zhao, J., Lou, J., Mou, Y., Li, P., Wu, J., \& Zhou, L. (2011). Diterpenoid tanshinones and phenolic acids from cultured hairy roots of Salvia miltiorrhiza Bunge and their antimicrobial activities. Molecules, 16, 2259-2267. 